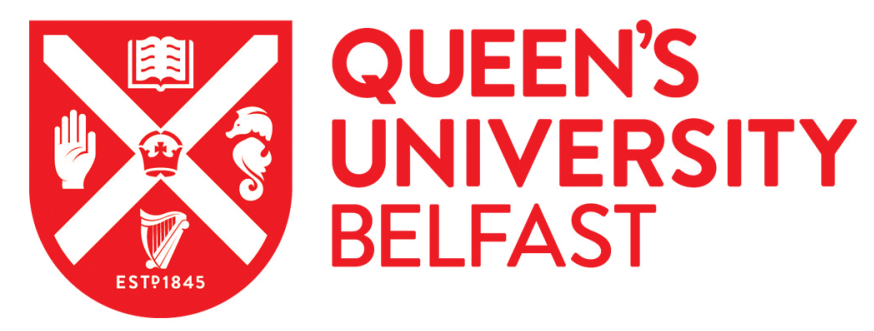

\title{
HRM and Innovation: The Mediating Role of Market-Sensing Capability and the Moderating Role of National Power Distance
}

Lin, C-H., Sanders, K., Sun, J-M., Shipton, H., \& Mooi, E. A. (2018). HRM and Innovation: The Mediating Role of Market-Sensing Capability and the Moderating Role of National Power Distance. International Journal of Human Resource Management. https://doi.org/10.1080/09585192.2018.1474938

Published in:

International Journal of Human Resource Management

Document Version:

Peer reviewed version

Queen's University Belfast - Research Portal:

Link to publication record in Queen's University Belfast Research Portal

Publisher rights

Copyright 2018 Taylor and Francis. This work is made available online in accordance with the publisher's policies. Please refer to any applicable terms of use of the publisher.

\section{General rights}

Copyright for the publications made accessible via the Queen's University Belfast Research Portal is retained by the author(s) and / or other copyright owners and it is a condition of accessing these publications that users recognise and abide by the legal requirements associated with these rights.

Take down policy

The Research Portal is Queen's institutional repository that provides access to Queen's research output. Every effort has been made to ensure that content in the Research Portal does not infringe any person's rights, or applicable UK laws. If you discover content in the Research Portal that you believe breaches copyright or violates any law, please contact openaccess@qub.ac.uk. 


\title{
HRM and Innovation: The Mediating Role of Market-Sensing Capability and the Moderating Role of National Power Distance
}

\author{
Abstract \\ This paper examines the mechanism through which human resource \\ management (HRM) practices promote firms' innovation and how this \\ relationship differs across cultures. Based on a dataset of 3,755 firms from 13 \\ countries, this study finds that in most countries employee-oriented HRM \\ practices that dedicate attention to employee needs and interests are positively \\ related to firms' market-sensing capability, which is the capability to \\ continuously learn about their markets. Market-sensing capability is in turn \\ significantly related to firms' product and process innovation. Cross-country \\ examination further reveals that in high power distance countries employee- \\ oriented HRM practices have a stronger positive effect than in low power \\ distance countries. This study highlights the importance of HRM in supporting \\ the use organizations make of external knowledge, which is critical for \\ organizational innovation. Bringing an external perspective, we complement \\ existing literature that emphasizes the role of HRM in integrating internal \\ knowledge. Our cross-cultural findings contribute to the understanding of \\ cultural contingency in HRM theories.
}

Keywords: employee-oriented HRM, innovation, market-sensing capability, power distance, international management 


\section{Introduction}

As the business environment becomes increasingly turbulent, innovation as a way to capture emerging market needs and sustain competitive advantage becomes more important. Consequently, there is surging interest among both practitioners and academics in how organizations can promote innovation. Extensive scholarship has asserted and demonstrated that human resource management (HRM) is crucial for firms' innovation (e.g., Shipton, West, Dawson, Birdi and Patterson, 2006; Chen and Huang, 2009; Liu, Gong, Zhou and Huang, 2016).

While there is evidence about a positive relationship between HRM and firm innovation, the mechanisms that underlie this relationship and the boundary conditions are less well understood (Seeck and Diehl, 2016; Lin and Sanders, 2017). First, although researchers recognize that innovation derives from knowledge both invented within a firm and obtained from external stakeholders (Zahra and George, 2002), empirical research on the HRMinnovation relationship has primarily focused on the utilization of internal knowledge (Foss, Laursen and Pedersen, 2011). Most existing studies examine how HRM encourages knowledge sharing within the organization (e.g., Collins and Smith, 2006; Chen and Huang, 2009; Lopez-Cabrales, Perez-Luño and Cabrera, 2009). This approach advocates the internal development of human resources (Lepak and Snell, 2002) and taps into the knowledge already possessed by employees. Only recently have researchers started to explore how HRM enables firms to obtain external knowledge (Chang, Gong, Way and Jia, 2013; Zhou, Hong and Liu, 2013), such as knowledge from partners.

The shift of emphasis from internal to external knowledge in the HRM-innovation research is not surprising. It is consistent with the spirit of 'open innovation' (Chesbrough, 2003) which maintains that in the new era, organization could not solely rely on knowledge created by its own employees. It has to acquire knowledge from outside of the organization as 
well. External knowledge resides in different sources. Some knowledge resources to trigger innovation can be found only with customers, competitors and suppliers on markets (Ahuja and Katila, 2001; Foss et al., 2011). The ability to continuously learn about markets was coined in the term 'market-sensing capability' (Day, 1994a). Superior market-sensing capability is a critical factor driving innovation (Olavarrieta and Friedmann, 2008). However, it is not yet clear what HRM practices can support the development of market-sensing capability. This presents a significant gap, as acquisition and dissemination of external knowledge have to be supported by management practices (Foss et al., 2011). Indeed, marketing scholars have called for inter-functional cooperation to build organizations attuned to markets (Narver and Slater, 1990). HRM scholars also contend that to create value, HRM has to help organizations to gain deep understanding of external business realities (Ulrich and Brockbank, 2005).

Second, research has found that the recipients of HRM practices from various cultures respond differently (Rabl, Jayasinghe, Gerhart and Kühlmann, 2014) due to the different 'programming' of their mind (Hofstede, 1980). As to innovation, despite the belief that certain cultures (e.g., high power distance and high uncertainty avoidance) might increase resistance to change and innovation (Jones and Davis, 2000; Erez and Nouri, 2010), how culture could influence people's reaction to HRM practices and thereby affect innovation outcomes is not yet well understood. This lack of understanding has significant consequences, for we are unsure whether or to what extent the HRM practices intended to promote innovation will be endorsed by employees given their cultural background.

This study aims to address these limitations. Taking a social exchange (Blau, 1964) and an organizational learning (Huber, 1991) perspective, this study examines the effect of employee-oriented HRM practices on firms' product and process innovation through development of their market-sensing capability. Employee-oriented HRM practices are HRM 
practices that manifest the managerial attention dedicated to the interests and needs of employees (Greenley and Foxall, 1997; Greenley, Hooley and Rudd, 2005). They signify management's support to employees and can influence employee attitudes and behaviors (Plakoyiannaki, Tzokas, Dimitratos and Saren, 2008) which are critical for employees' engagement with different stakeholders (Bowen, Schneider and Kim, 2000; Nishii, Lepak and Schneider, 2008). Their engagement, as we argue later, is a prerequisite for collecting and distributing market-related information.

Further, we examine the role of national culture - to be specific, power distance - in moderating the relationship between employee-oriented HRM practices and innovation. Power distance is the extent to which the members of a society accept unequal power distribution in institutions and organizations (Hofstede, 1980; Carl, Gupta and Javidan, 2004). It has been consistently found to discourage innovation, because the hierarchical structure in high power distance countries inhibits communication and suppresses change (Rinne, Steel and Fairweather, 2012). Whether employee-oriented HRM practices, which, as we argue later, essentially reduce power difference, would work more effectively in high power distance countries has important implications. According to this argument, HRM practices might mitigate the negative influence of high power distance on innovation. Such a contingency perspective also speaks to calls to further highlight the effect of context on the HRMperformance relationship (Boxall and Macky, 2009; Rabl et al., 2014).

This study aims to make the following contributions to the HRM-innovation research: First, although strategy and marketing researchers have emphasized the importance of market knowledge to innovation, HRM researchers have been primarily inward looking (Foss et al., 2011). With the advent of an 'open innovation' era (Chesbrough, 2003), it is becoming increasingly important for firms to acquire external knowledge. By introducing marketsensing capability into the HRM-innovation linkage research, this study investigates the role 
of HRM in facilitating the acquisition of external market knowledge. Second, this study addresses cultural contingency in the HRM-innovation relationship. It answers the question as to whether employee-oriented HRM practices are more effective in high or low power distance countries to foster innovation. It joins the discussions on the generalizability of HRM theories and contributes to the international HRM literature (Bamberger, 2008; Rabl et al., 2014).

\section{Conceptual Framework and Hypotheses}

\section{HRM and innovation: prior research}

Primary evidence of a positive relationship between HRM and innovation has been documented by emerging research in recent years (see the review of Seeck and Diehl, 2016). A number of theoretical views are offered to explain this relationship. A prominent one is arguably the knowledge-based view in which the generation of knowledge is regarded as the driver of innovation. This can be attributed to the knowledge-intensive nature of innovation (Lin and Sanders, 2017). Derived from this view, knowledge management capacity (e.g., Collins and Smith, 2006; Chen and Huang, 2009; Chang et al., 2013) and organizational learning (e.g., Shipton, Fay, West, Patterson and Birdi, 2005; Lin and Sanders, 2017), among others, are argued to explain how HRM fosters innovation.

While in the last two decades a large proportion of HRM literature has been devoted to opening the black box between HRM and performance (Lepak, Takeuchi, Erhardt and Colakoglu, 2006), the findings in the HRM-innovation research can only be described as scattered (Seeck and Diehl, 2016). Out of 35 studies they reviewed, Seeck and Diehl (2016) found that 13 examined the indirect relationship between HRM and innovation. The mediating variables range from employee creativity and innovative behaviors (Jiang, Wang and Zhao, 2012; Fu, Flood, Bosak, Morris and O'Regan, 2015) over organizational 
knowledge management capacities (Chen and Huang, 2009) to innovative culture (Lau and Ngo, 2004). Most of these studies take an internal view and focus on how to bring out the knowledge already possessed by employees. Only recently has the emphasis started to shift outwards (Chang et al., 2013; Zhou et al., 2013). Moreover, eight studies examined the moderators of the HRM-innovation relationship. Organizational strategy and structure (e.g., Perdomo-Ortiz, Gonzalez-Benito and Galende, 2009) and operational environment (e.g., Cooke and Saini, 2010) are among the examined factors. Despite evidence of a direct effect of national cultures on innovation (e.g., Rinne et al., 2012), few studies, if any, have investigated national culture as a moderator between HRM and firm innovation.

\section{Our perspective}

In light of the limitations highlighted above, this study joins scholarly efforts to reveal the mediating mechanisms between HRM and innovation and uncover any potential cultural contingencies of these relationships. We derive our position from social exchange theory (Blau, 1964) and organizational learning theory (Huber, 1991). Social exchange theory argues that employees receiving organizational support feel obligated to reciprocate the organization in a way consistent with the organization's objectives. This theory is fundamental in explaining the HRM-performance relationship (Takeuchi, Chen and Lepak, 2009). Employees' interpretations of organizational support may, nevertheless, depend on whether the management practices 'fit' with employees' entrenched cultural values (Newman and Nollen, 1996).

Organizational learning is central to innovation. It is claimed as the principal process by which innovation occurs (Stata, 1989). Huber (1991) takes a behavioral perspective towards learning and contends that 'an entity learns if, through its processing of information, the range of its potential behaviors is changed' (p.89). Huber articulates four processes integrally linked to organizational learning: knowledge acquisition, information distribution, 
information interpretation and organizational memory. In this study, we focus on the first two processes, because, as we explain in the next section, employees are more involved in these two processes, whereas the latter two processes largely fall within the remit of managers.

\section{Employee-oriented HRM practices and market-sensing capability}

Market-sensing capability is the ability to continuously learn about markets in order to sense and act on the events and trends in current and prospective markets (Day, 1994a; Fang, Chang, Ou and Chou, 2014). The process of sensing markets involves all four organizational learning processes (Day, 1994a). That is, firms enquire into their markets for customer demands, competitors move, technical evolution, supplier responses and alike. The acquisition of market knowledge facilitates the absorption of critical knowledge from the stakeholders at external markets (Laursen and Salter, 2006). The acquired information then is distributed across the firm, which paves the way for effective integration (Kale and Singh, 2007). The information is further interpreted and acted on, facilitated by the mental models of managers (Day, 1994a). If the evaluation of the outcomes suggests that markets responds as expected, the new knowledge will be stored in organizational memory, such as policies, procedures and rules. Employees are at the frontline of the organization-market interface and are sensors of organizations (Day, 1994b). In the four learning processes leading to marketsensing capability, employees play a vital role in knowledge acquisition and distribution (Plakoyiannaki et al., 2008), whereas managers play a larger role in synthesizing, interpreting the knowledge and institutionalizing it into organizational routines (Nonaka and Takeuchi, 1995). Hence, HRM practices applied to employees can influence firm's market-sensing capability mainly through affecting the first two learning processes.

'Employee-oriented HRM practices' in this study borrows its name from the 'employee orientation' in the multiple stakeholder orientation construct (Greenley et al., 2005). Multiple stakeholder orientation reflects the priority and attention an organization gives to each of its 
stakeholders (Greenley and Foxall, 1997; Greenley et al., 2005). As to the employee group, employee orientation signifies the managerial attention dedicated to the needs and interests of employees. Because HRM practices are activities associated with the management of work and people (Boxall and Purcell, 2011) and are the primary means through which an organization communicates to employees (Guzzo and Noonan, 1994; Bowen and Ostroff, 2004), employee orientation is primarily manifested through HRM practices. Practices covered in Greenley et al. (2005) include performance appraisal oriented towards employee developmental needs, regular staff meetings, managers' inquiry about employees' feelings towards their job, and employee attitude surveys. These practices underline the efforts made by management to identify and meet employee needs. They also offer opportunities for communication between managers and employees, particularly for employees' upward communication. Research shows that open communication with management increases employees' perceived organizational support, by signaling that the organization cares about employees' well-being and values their contribution (Neves and Eisenberger, 2012). We define these HRM practices conveying an organization's employee orientation as 'employeeoriented HRM practices'.

Employee-oriented HRM practices share some features with high commitment HRM (Arthur, 1994). Both forge a trusting bond between the organization and its employees and foster a long-term exchange relationship. Despite the similarity, employee-oriented HRM practices have a particular focus on upward communication opportunities. When employees can freely share information and views with their managers, it allows the latter to stay in touch with their employees and detect emerging trends and problems in the marketplace (Tourish, 2005). Given that innovation heavily relies on information sharing to find unknown knowledge and integrate knowledge in a novel way (Nonaka, Toyama and Nagata, 2000; Camelo-Ordaz, Garcia-Cruz, Sousa-Ginel and Valle-Cabrera, 2011; Lin and Sanders, 2017) 
and given the impact of power distance on communication across hierarchies (Morrison and Milliken, 2000; Koc, 2013), such a focus has unique value for this study.

Employee-oriented HRM practices likely contribute to the development of firms' marketsensing capability by facilitating the acquisition and distribution of market knowledge. Employee-oriented HRM practices induce supportive relationships within an organization. Such relationships spill over to customer-firm interactions (Plakoyiannaki et al., 2008). Studies find that customer-facing employees reciprocate management support by proactively probing customer demands and communicating the acquired information upward (e.g., Schneider and Bowen, 1985; Peccei and Rosenthal, 2001). Feeling supported, they invest extra efforts in understanding customers' specific needs (Schneider and Bowen, 1985; Vandenberghe et al., 2007). In addition, employees are also involved in collecting competitor information (Pass, Evans and Schlacter, 2004). Management support is found to positively relate to employees' intelligence generation behaviors, possibly because it engenders trust on the part of employees (Conduit and Mavondo, 2001). They report on customer demands and competitors' moves, trusting that their intelligence-gathering efforts will pay off in the long term.

Employees serve as the contact point between a firm and its market. For market information to be transferred into the firm, internal communication is required for the information to be distributed within the organization (Foss et al., 2011). Unimpeded upward communication requires a culture of openness that encourages debate and feedback. This only happens in a supportive environment where employees' fear and concerns are removed (Vuori and Huy, 2016). Employee-oriented HRM practices convey a message that management is receptive to employee voices. Practices such as regular staff meetings and managers' proactive enquiries provide opportunities for employees to communicate the information they have gathered. 
Taken together, employee-oriented HRM practices foster a positive exchange relationship within organizations and induce reciprocating behaviors from employees. As sensors of a firm, employees engage in acquiring information from different sources and sharing it with managers. The knowledge acquisition and distribution processes are essential processes for organizational learning about the markets (Day, 1994a), leading to the development of a superior market-sensing capability.

Hypothesis 1: Employee-oriented HRM practices positively relate to firms' marketsensing capability.

\section{Market-sensing capability and firm innovation}

Market-sensing capability is crucial for firm innovation. As firms gain better understandings of dynamic and sometimes latent customer demands and continuously evolving competitor strategies, their insights can lead to new technologies and new patterns of activities (Priem, Li and Carr, 2012), which result in product and/or process innovation. Product innovation refers to new output from an organization, including new services and products, whereas process innovation refers to new elements introduced into the way of working (Rowley, Baregheh and Sambrook, 2011).

In high-velocity markets today, only those who innovate their products and services are able to win over customers. Yet there is an information asymmetry between firms and customers; that is, customers possess more information about their needs and the contexts of use of a product, whereas firms have more knowledge about generic solutions (von Hippel, 1998). Successful innovation requires a combination of both. Firms with superior marketsensing capability are able to detect the changes in customer needs. They are more likely to develop innovative solutions to meet the changes (Heusinkveld, Benders and van den Berg, 2009). Market-sensing in terms of competitor analysis involves benchmarking and identification of a firm's strengths and weakness against the competitors (Han, Kim and 
Srivastava, 1998). This compels firms to modify and innovate their own products and processes in order to reduce the threats posed by their competitors. Research finds a competitor orientation results in technical innovation (Han et al., 1998) and process reengineering (Radnor and Robinson, 2000).

Overall, insights into markets should guide the routines inside a firm and trigger innovation in products and processes (Johne, 1999; Priem et al., 2012). Firms with superior market-sensing capability are more likely to find market niches for targeting new products or services. They are also more likely to identify new, better work procedures. Damanpour and Aravind (2006) find that 'most determinants (of innovations) do not differentiate between product and process innovations; when they do, the difference is more of degree than direction of the effect' (p.38). Hence, we expect the same direction of relationship between market-sensing capability and product and process innovation. We propose that:

Hypothesis 2: Market-sensing capability positively relates to firms' (a) product innovation and (b) process innovation.

\section{Mediating effect of market-sensing capability}

Combining hypothesis 1 and 2, we propose that market-sensing capability mediates the relationship between employee-oriented HRM practices and innovation. Employee-oriented HRM practices signal management's care for employees (Greenley and Foxall, 1997; Greenley et al., 2005) and the organization's willingness to engage in a long-term exchange relationship with employees. To reciprocate, employees engage in collecting business-related information to benefit the organization. Employee-oriented HRM practices also shape an environment in which open communication between managers and employees is more likely to happen. This further enhances the sharing of acquired knowledge. Market-sensing capability accrued from these processes enables firms to capture changing trends and identify opportunities to reflect trends through new products, services and processes. 
While previous research has emphasized the role of HRM in bringing out the latent knowledge of employees in innovation, much less attention has been paid to their role in developing firms' market knowledge (Foss et al., 2011), even though marketing researchers have repeatedly emphasized its importance (e.g., Johne, 1999; Kirca, Jayachandran and Bearden, 2005). Filling this gap, we propose that market-sensing capability presents an important mechanism explaining the HRM-innovation nexus. Because we expect that employee-oriented HRM practices will also motivate employees to share internal knowledge, we propose a partial mediation of market-sensing capability.

Hypothesis 3: Market-sensing capability partially mediates the relationship between employee-oriented HRM practices and (a) product innovation and (b) process innovation.

\section{The moderating effect of national power distance}

Power is fundamental to all relationships in organizations. The extent to which people accept power inequality (i.e., power distance) affects many organizational processes and outcomes, primarily through shaping how individuals with differing levels of power interact (see the review of Daniels and Greguras, 2014). Despite findings suggesting that HRM practices 'fit' with local power distance translate into favorable outcomes (Newman and Nollen, 1996; Robert, Probst, Martocchio, Drasgow and Lawler, 2000; Zhang and Begley, 2011), recent large-scale meta-analysis (Rabl et al., 2014) shows that the opposite might be true. Indeed, Carl et al. (2004) have hinted that gains from practices that eliminate power inequality might be particularly high in high power distance cultures. The rationale is explained by Maseland and Hoorn (2009) who draw on insights from microeconomics to argue that when an objective is satiated, the importance people attach to it will decline; that which is scarce is generally valued highly. The GLOBE data shows that there is a negative relationship ( $\mathrm{r}=-.43, \mathrm{p}<.01)$ between "as is" and "should be" power distance measures 
(Carl et al., 2004), suggesting that in societies where high power distance practices are prevalent, people prefer to experience an equitable distribution of power.

Employee-oriented HRM practices attend to employee developmental needs and offer multiple opportunities for upward communication. These practices are contrary to common practices in high power distance countries, for in high power distance countries developmental resources are accessible only to a few people (Sturman, Shao and Katz, 2012). Due to stratification based on status, there is less communication between managers and employees (Morrison and Milliken, 2000) and communication tends to be less open (Koc, 2013). In line with the reasoning of Maseland and van Hoorn (2009), we expect that employees in these countries will appreciate employee-oriented HRM practices to a greater extent, because their need for development and for open communication may not otherwise be met. They may engage in knowledge acquisition and sharing behaviors more frequently to reciprocate. This could in turn lead to higher market-sensing capability. Hence, we expect the relationship between employee-oriented HRM practices and market-sensing capability is stronger in high power distance countries.

Moreover, in high power distance countries people prefer to champion an idea to management first and gain support; whereas in low power distance countries, people tend to build a base of support from lower-level members, which slows down the innovation process (Shane, Venkataraman and MacMillan, 1995). The different championing strategies mean that firms in high power distance countries might have more to gain from employee-oriented HRM practices, since such practices, we argue, remove barriers in the upward communication process and make direct championing to management more straightforward. This could shorten the promotion stage in innovation and allow firms employing these HRM practices to produce innovations more quickly as a result. Hence, we expect that employeeoriented HRM practices would result in more product and process innovations in high power 
distance countries than in low power distance countries by virtue of the different championing strategies employed. In sum, we propose:

Hypothesis 4: National power distance moderates the direct relationship between employee-oriented HRM practices and market-sensing capability, such that the relationship is stronger in high power distance countries than in low power distance countries.

Hypothesis 5: National power distance moderates the direct relationships between employee-oriented HRM practices and (a) product innovation and (b) process innovation, such that the relationships are stronger in high power distance countries than in low power distance countries.

Below in Figure 1 is the conceptual model.

Figure 1 here

\section{Methodology}

\section{Sample and data collection}

The present study uses data collected for the project 'Marketing in the 21st Century' between 2002 and 2005. The data in this study included 13 countries: the United Kingdom, Ireland, Austria, Finland, New Zealand, Australia, Hungary, Greece, Germany, Slovenia, the Netherlands, the United States, and Brazil.

A sampling frame based on an established business directory (including Dun and Bradstreet, ProBusiness, Ireland Kompass and TOY-research) was employed for each country. An academic in each country contacted the chief marketing officers of a stratified number of firms based on firm size, industry and market type. Not-for-profit firms and firms with less than 20 employees were excluded. Industries in the sample cover banking, telecommunications, pharmaceutical manufacturing, automotive production, energy and shipping. In cases where a firm did not have a chief marketing officer, the general manager or 
chief executive officer was invited. The marketing officers were well informed about their marketing capabilities and innovation. Because they held a managerial position, they also knew the firm's approach towards employees. Confidentiality was assured to all the participants. A follow-up survey was sent if no response was received after two weeks. The net response from the 13 countries was 4,771 firms. After deletion of samples with missing data on the variables of interest, the final analysis retained 3,755 firms.

Researchers developed the questionnaire in the UK, where they extensively pilot tested it to refine the measurement. Because the original measures were all in English, translation and backtranslation (Brislin, 1970) were conducted for non-English speaking countries to ensure that the meaning of the questionnaires was equivalent. Table 1 includes a breakdown of the sample size, the language used in the survey and the net response rate in each country.

------- Table 1 here--------

\section{Measures}

Employee-oriented HRM practices were measured using the scale developed by Greenley et al. (2005) as one dimension of the multiple stakeholder orientation. The scale was originally developed to measure a firm's employee orientation, but the questions tap into HRM practices. Some items included in this scale (e.g., developmental performance appraisal and attitude survey) have appeared in high-commitment work practice measures given their conceptual overlap (e.g., Whitener, 2001; Xiao and Björkman, 2006). The response options ranged from (1) 'strongly disagree' to (5) 'strongly agree'. The Cronbach's alpha in the pooled sample was .75 .

Market-sensing capability. This study developed two items to capture firms' marketsensing capability based on the conceptual work of Day (1994a). They are (1) 'good at using information about markets, customers and competitors' and (2) 'good at understanding what customer needs and requirements are' compared to a firm's competitors. Similar items to 
measure market-sensing capability are used in Morgan, Slotegraaf and Vorhies (2009). Options ranged from (1) 'strong competitors' advantage' to (5) 'our strong advantage'. The Cronbach's alpha in the pooled sample was .59.

Product innovation. This scale consists of two items taken from Hooley, Broderick and Möller (1998). The respondents rated the degree of innovation and the uniqueness of their products and services compared to their main competitors. The options ranged from (1) 'much lower than competitors' to (5) 'much higher than competitors'. The Cronbach's alpha in the pooled sample was .70.

Process innovation. This scale consists of four items adapted from West and Anderson (1996) to measure a firm's process innovation. The same measure appeared in Luk et al. (2008). Respondents assessed their firm's innovativeness in initiating changes in work procedures and methods. A sample item is 'we are more innovative than our competitors in initiating new procedures or systems'. Response options ranged from (1) 'strongly disagree' to (5) 'strongly agree'. The Cronbach's alpha in the pooled sample was .89.

Control variables. We controlled for industry, size, and market competition of the respondents' firms in the analysis due to their potential impact on market-sensing capability and innovation. The number of employees is used as a proxy of a firm's size (small firms < 100 employees; $100 \leq$ medium firms $\leq 499$ employees; large firms $\geq 500$ employees). The market competition scale consists of five items used by Greenley and Foxall (1998). A sample item is 'new products and services are coming to market more quickly than in the past'. The Cronbach's alpha of this scale in the pooled sample was .61. 


\section{Results}

\section{Measurement equivalence}

Testing the hypotheses in multiple countries requires establishing configural and metric invariance of the measures (cf. Cheung and Rensvold, 2002). We first tested for configural invariance of the constructs in a multigroup nested model, with the items loaded on their related latent constructs. The model yielded configural invariance across 13 countries $\left(\chi^{2}(1,417)=1,944.02, p<.01, \mathrm{CFI}=.97, \mathrm{TLI}=.96, \mathrm{RMSEA}=.04\right)$. Although the chi-square was significant, this index is a function of sample size and tends to be significant as the sample size increases (Bentler and Bonett, 1980). The CFI and TLI were both above .95 and the RMSEA was below .08 (Hu and Bentler, 1999), indicating good fit with the data. We then tested for metric invariance by constraining the factor loadings of each item to be equal in all the countries. The discrepancies of CFI and TLI between the configural and metric models were below or equal to $.01(\mathrm{CFI}=.96, \mathrm{TLI}=.95, \Delta \mathrm{CFI}=.01, \Delta \mathrm{TLI}=.01)$, providing evidence for metric invariance (Cheung and Rensvold, 2002). This shows that the measurement is equivalent across countries.

\section{Common method variance}

Because all the data came from a single source at the same time, the research results might be subject to common method bias (Podsakoff, MacKenzie and Podsakoff, 2012). This study applied a marker variable technique (Lindell and Whitney, 2001). Lindell and Whitney (2001) propose inclusion of a scale that is theoretically irrelevant to at least one other scale in the questionnaire. This means a zero correlation between the two scales is expected. Then the smallest correlation between the marker variable and the substantive variables provides a reasonable proxy for the method variance. This study used the pricing strategy of a firm as the marker variable, expecting that it has a minimal relationship with a firm's HRM practices. The pricing strategy scale includes two items: "we set prices on the basis of costs of 
producing plus a fixed margin for profit' and 'we set prices based on what the market is prepared to pay' (reverse coded). The same response anchors as for the substantive variables were used. Such shared method characteristic is a desirable attribute of a marker variable (Podsakoff et al., 2012). The reliability of this scale was .59. The analysis revealed that the smallest correlations between the marker variable and the substantive variables in the 13 countries ranged from .00 to .09 and none of them was significant. Thus, common method bias is less likely a big concern in the data.

\section{Hypothesis testing}

This study used Structural Equation Modeling (SEM) as the analysis strategy. Table 2 presents the correlation matrix and descriptive statistics of all the constructs in the pooled sample. We first tested hypotheses $1-3$ by allowing the paths in each country to be estimated separately. The overall fit of the structural models is acceptable $\left(\chi^{2}(2,688)=4,219.91, \mathrm{CFI}\right.$ $=.92, \mathrm{TLI}=.90, \mathrm{RMSEA}=.04, \mathrm{SRMR}=.06)$. The study also estimates the path coefficients in the pooled sample. The fit indexes are: $\chi^{2}(221)=939.15, \mathrm{CFI}=.96, \mathrm{TLI}=.95, \mathrm{RMSEA}$ $=.03, \mathrm{SRMR}=.03$. Table 3 presents the results in each country and in the pooled sample. -------- Table 2 and 3 near here--------

Hypothesis 1 states that employee-oriented HRM practices positively relate to firms' market-sensing capability. This hypothesis received support in most countries, except for Finland $(\beta=.10$, n.s. $)$ and New Zealand $(\beta=.10$, n.s. $)$. In Australia $(\beta=.23)$ and Austria (.32), the paths were significant at .10 level. In countries where there was a positive and significant relationship, the standardized path coefficients ranged from $.25(p<.01$; UK) to $.52(p<.01$; Germany). In the pooled sample, the path coefficient was $.28(p<.01)$.

Hypothesis $2 \mathrm{a}$ states that market-sensing capability relates positively to product innovation. This hypothesis received support in all countries (although Austria is the only country where the significance level was at .10 level). The standardized path coefficients 
ranged from $.24(p<.01 ; \mathrm{UK})$ to $.61(p<.01$; Brazil). In the pooled sample, the path coefficient was $.43(p<.01)$. Hypothesis $2 \mathrm{~b}$ states that market-sensing capability relates positively to process innovation. This hypothesis received support in all countries, with the standardized coefficients ranging from .28 ( $p<.01$; New Zealand) to $.72(p<.01 ;$ Finland). In the pooled sample, the path coefficient was $.49(p<.01)$. Product innovation and process innovation were positively associated with each other in all countries but Finland $(\mathrm{r}=.11, n . s$. and Austria $(\mathrm{r}=.29$, n.s. $)$. In the pooled sample, this correlation was $.44(p<.01)$.

Hypothesis 3a states that market-sensing capability partially mediates the relationship between employee-oriented HRM practices and product innovation. To test mediation and assess the significance of the indirect effect, we used bootstrapping procedures (Preacher and Hayes, 2004). We resampled 10,000 times to create $95 \%$ confidence intervals of the indirect effects. When a confidence interval excludes zero, the mediation effect is significant. The $95 \%$ confidence intervals are reported in Table 3 . The results show that the partial mediation hypothesis received support only in Ireland. Surprisingly, market-sensing capability fully mediated the relationship between employee-oriented HRM practices and product innovation in the US, the UK, Germany, Brazil, Slovenia, Greece and Hungary. In the Netherlands and Australia, the mediation effect was significant at .10 level. In New Zealand, Finland and Austria the mediation effect was not significant. In the pooled sample, the indirect effect was significant.

Hypothesis $3 \mathrm{~b}$ states that market-sensing capability partially mediates the relationship between employee-oriented HRM and process innovation. This hypothesis received support in Ireland, Slovenia, Greece, and Hungary. In the Netherlands, the US, the UK, Germany, and Brazil, market-sensing capability fully mediated the relationship between employee-oriented HRM and process innovation. The mediation effect was significant at .10 level in Australia, 
but not significant in New Zealand, Finland and Austria. In the pooled sample the indirect effect was significant.

To test hypothesis 4 and 5, we classified the countries into two groups based on the power distance practice scores in the GLOBE project, because the data from the GLOBE study are more recent. We focus on practices instead of values because the former is a better indicator of the real context in which HRM operates. The median of the power distance practice scores in the 13 countries was 5.15. Six countries (Finland, the Netherlands, Australia, US, New Zealand and Austria) with scores lower than the median were in the low power distance country group, and seven countries (Ireland, UK, Germany, Brazil, Slovenia, Greece and Hungary) with scores equal to or above the mean were in the high power distance country group. The mean power distance practices scores in the two groups were 4.74 and 5.31, respectively, which were significantly different from each other $(t=-4.25, p<.01)$. The sample sizes in the two groups were 1,313 (low power distance) and 2,442 (high power distance), respectively.

We compared the path coefficients in the two country groups using multiple group analysis. The results show that the path coefficient between HRM and market-sensing capability was $.22(p<.01)$ in the low power distance countries and $.33(p<.01)$ in the high power distance countries. Following the recommendation of Cheung and Lau (2011), we created a difference term by subtracting the coefficient in the high power distance country group from that in the low power distance country group. The estimate of the difference term was -.06 . Its $95 \%$ confidence interval was constructed by bootstrapping 10,000 times ([-0.13, $0.01])$, which included zero. However, the $90 \%$ confidence interval is $[-0.119,-.001]$ and excluded zero. Therefore, the relationship between employee-oriented HRM and marketsensing capability in the low power distance countries was weaker than that in the high power distance countries at .10 level. Hypothesis 4 received marginal support. 
Using the same approach, we find that the path coefficients between employee-oriented HRM practices and product innovation in the two country groups were significantly different. It was -.04 (n.s.) in the low power distance countries and $.08(p<.01)$ in the high power distance countries (difference termlow-high $=-.09, \mathrm{CI}_{95 \%}=[-.17,-.01]$, excluding zero). Thus, hypothesis 5a was supported. However, the path coefficients between employee-oriented HRM practices and process innovation were not significantly different from each other. It was $.17(p<.01)$ in the low power distance countries and $.20(p<.01)$ in the high power distance countries (difference termlow-high $=-.02, \mathrm{CI} 95 \%=[-.10, .07]$, including zero). Therefore, hypothesis $5 \mathrm{~b}$ received no support. No other paths were significantly different in the two country groups. The results appear in Figure 2.

Figure 2 here

\section{Discussion}

The purpose of this research is to examine whether market-sensing capability mediates the relationship between HRM and innovation and further, whether the relationships vary in different cultures. The results demonstrate that in most of the sampled countries full or partial mediation was found. The strength of the relationships was contingent upon national power distance. In high power distance countries, employee-oriented HRM practices were more strongly related to market-sensing capability and product innovation.

\section{Theoretical Implications}

The results of this study have several theoretical implications for the HRM-innovation linkage research. First, although external knowledge is vital for innovation (Priem et al., 2012; Zhou and Li, 2012), HRM researchers have not sufficiently integrated markets as sources of knowledge into their research. Chesbrough (2003) claims that in the open innovation era it is more important for firms to combine knowledge from multiple sources rather than to create 
their own knowledge. This study is one of the first to establish the relationship between HRM practices and market-sensing capability. It shows that there is much to gain if researchers take a multidisciplinary approach and incorporate the findings from other fields (such as marketing) into the HRM-innovation research.

Second, this study shows that HRM practices dedicated to addressing employee needs and reducing power distance within organizations are particularly useful in eliciting innovation in high power distance countries. It seems that a high power distance context produces a contrast effect for these practices. Employer's willingness to care for employees becomes all the more salient against that context and is more appreciated. This finding poses a challenge to the 'cultural fit' model which posits that practices congruent with the local culture are more likely to produce favorable outcomes (Aycan, Kanungo and Sinha, 1999). Indeed, although the mainstream perspectives advise firms to follow common local practices to achieve cultural fit and gain legitimacy, recently researchers have begun to cast doubt on this view and argue that automatic conformance to the local cultural norm is not necessarily the most effective strategy (Gelfand, Nishii and Raver, 2006; Heugens and Lander, 2009).

The point made above may be particularly true when innovation is concerned. Innovation relies much on open discussions and information sharing to find unknown knowledge to allow novel integration (Lin and Sanders, 2017). High power distance accentuates the status difference between people and blocks information flow. This could harm employees' motivation, impede organizational learning and stifle firms' innovation. The study suggests that firms in high power distance countries may be particularly rewarded by unleashing employees from long-standing cultural constraints and encouraging them to speak up. 


\section{Managerial Implications}

This study offers several important practical implications for managers. First, continuously learning about markets including customers and competitors is crucial for organizational innovation, because the identification of opportunities and threats through market sensing is a critical trigger of change (Priem et al., 2012). Developing superior market-sensing capability entails significant employee engagement, especially from front-line contact employees (Day, 1994b). Firms need to dedicate resources to address employee needs so that a long-term bond can be forged with employees and they work in the best interests of the organization. Further, communication mechanisms should be in place so that employees can freely share their knowledge with management.

Second, this study provides unique implications for firms entering or operating in high power distance countries, where hierarchy in social structure is clear. This study suggests that the advice 'when in Rome, do as the Romans do' warrants scrutiny (Rabl et al., 2014) when it relates to innovation. In high power distance countries, it might be particularly important that firms break the fault line between management and employees. This would offer motivation and opportunities for knowledge sourcing and sharing, which benefit innovation.

Third, in high power distance countries, companies striving for innovation could use egalitarian management practices to attract and motivate local talents who yearn for equality (Caprar, 2011). Nonetheless, the caveat is that it may be difficult to initiate egalitarian practices in these countries because people are accustomed to following instructions and directives (Carl et al., 2004). Proper support should be put in place for firms to take full advantage of the egalitarian practices.

\section{Limitations and Future Research Directions}

This research has several limitations which point to future research directions. First, the cross-sectional nature of the data excludes inference of causality. The test of mediation is 
stronger using longitudinal data. Further, the data were collected about a decade ago and the business environment has experienced changes in the intervening time. For example, sophisticated data technologies have been developed to track market trends and feed into innovation decisions (Chen, Chiang and Storey, 2012), which may replace part of the business intelligence function of front-line employees. Nevertheless, it is argued that technologies and the large volume of data collected do not have the power to unambiguously reveal what customers are thinking, nor do they clearly uncover unmet or poorly met needs (Forsyth and Boucher, 2015). Therefore, human factors in gaining market insights are indispensable (Agarwal and Weill, 2012). The increasing dynamism in the environment may just make the role of employees in market-sensing ever more important.

Second, this study sampled the chief marketing manager in each firm. When it relates to HRM practices, chief marketing officers may not be as aware of HRM practices as an HR officer would be. Given the limited resources, the researchers nonetheless decided to obtain data from as many firms as possible rather than studying fewer firms with more respondents from each firm. Because an important purpose of this study is to compare cross-country differences, this decision is justifiable. Additionally, chief marketing officers may more accurately report how HRM is experienced in the organization as there is no pressure to 'talk up' the importance of HRM to aggrandize the profession. With that said, it is important to have other informants' perspective on HRM practices, such as employees'. Employee perceived HRM has gained research momentum in recent years (Nishii and Wright, 2008).

Third, because of the small number of countries and lack of statistical power, we did not conduct a multilevel analysis. Following previous research (e.g., Newman and Nollen, 1996), we dichotomized the countries at a theoretically meaningful point and conducted a multiple group analysis. Future studies having more countries in their sample can conduct a multilevel analysis. 
Fourth, this study includes a limited number of practices into the measure of employeeoriented HRM. Although previous research shows this measure has sufficient validity to capture firms' attention to employee interests and needs (Greenley et al., 2005), future research could include more practices to construct a more comprehensive measure. Marketsensing capability and product innovation were measured by two items due to the space limit of the questionnaire. Future studies could use measures that include more items and possibly render higher reliabilities.

Despite these limitations, this research and its results point to some interesting future research directions. First, this study verifies the role of HRM in fostering the use of external market knowledge. Different from integrating internal knowledge, this mechanism represents another route towards innovation. Future research can compare the magnitude of the internal and external route. Environmental contingencies accounting for the superiority of one route over another might be identified.

Second, this study only examines power distance as a relevant cultural dimension, given its direct theoretical relationship with employee-oriented HRM practices. Research has found that culture dimensions such as collectivism, masculinity, and uncertainty avoidance are also related to innovation (Shane, 1993). Future studies could identify HRM practices that are theoretically relevant to these cultural dimensions and examine whether their relationships with innovation differ across cultures. For example, well-defined rules (Newman and Nollen, 1996) and the structuring of HRM (Binyamin and Carmeli, 2010) could be aspects relevant to uncertainty avoidance.

Third, while there are cultural differences in the relationship between employee-oriented HRM practices and product innovation, it is not the case for process innovation. We suspect this is because process innovation contains both technical and administrative elements (Rowley et al., 2011) and administrative innovation tends to follow a 'top-down' path (Daft, 
1978). In high power distance countries, administrative innovation might be especially difficult to initiate, because this fundamentally changes the power structure in organizations. Hence, the positive effect of employee-oriented HRM practices on process innovation in high power distance countries might be partially cancelled out by this difficulty. Future studies investigating the initiation of product and process innovations in different cultures are warranted.

\section{Conclusion}

This study reveals a new mechanism through which HRM practices stimulate firms' product and process innovation. It highlights the necessity to incorporate markets as important sources of knowledge into the stream of HRM-innovation research. Further, this study finds that in high power distance countries the relationships between employee-oriented HRM practices and market-sensing capability and product innovation were stronger. These findings shed light on cultural contingency in HRM practices.

\section{References}

Agarwal, R. and Weill, P. (2012). The benefits of combining data with empathy, MIT Sloan Management Review, 54, 35-41.

Ahuja, G. and Katila, R. (2001). Technological acquisitions and the innovation performance of acquiring firms: A longitudinal study, Strategic Management Journal, 22, 197-220.

Arthur, J.B. (1994). Effects of human resource systems on manufacturing performance and turnover, Academy of Management Journal, 37, 670-687.

Aycan, Z., Kanungo, R.N. and Sinha, J.B. (1999). Organizational culture and human resource management practices the model of culture fit, Journal of Cross-Cultural Psychology, 30, 501-526.

Bamberger, P. (2008). Beyond contextualization: Using context theories to narrow the micromacro gap in management research, Academy of Management Journal, 51, 839-846.

Bentler, P.M. and Bonett, D.G. (1980). Significance tests and goodness of fit in the analysis of covariance structures, Psychological Bulletin, 88, 588-606. 
Binyamin, G. and Carmeli, A. (2010). Does structuring of human resource management processes enhance employee creativity? The mediating role of psychological availability, Human Resource Management, 49, 999-1024.

Blau, P.M. (1964). Exchange and Power in Social Life, New York: Wiley.

Bowen, D.E. and Ostroff, C. (2004). Understanding HRM-firm performance linkages: The role of the "strength" of the HRM system, Academy of Management Review, 29, 203-221.

Bowen, D.E., Schneider, B. and Kim, S.S. (2000). Shaping service cultures through strategic human resources management. in T.A. Swartz and D. Iacobucci (Eds.), Handbook of Services Marketing and Management, Thousand Oaks, CA: Sage.

Boxall, P. and Macky, K. (2009). Research and theory on high-performance work systems: progressing the high-involvement stream, Human Resource Management Journal, 19, 3-23.

Boxall, P. and Purcell, J. (2011). Strategy and Human Resource Management, Basingstoke: Palgrave Macmillan.

Brislin, R.W. (1970). Back-translation for cross-cultural research, Journal of Cross-Cultural Psychology, 1, 185-216.

Camelo-Ordaz, C., Garcia-Cruz, J., Sousa-Ginel, E. and Valle-Cabrera, R. (2011). The influence of human resource management on knowledge sharing and innovation in Spain: the mediating role of affective commitment, The International Journal of Human Resource Management, 22, 1442-1463.

Caprar, D.V. (2011). Foreign locals: A cautionary tale on the culture of MNC local employees, Journal of International Business Studies, 42, 608-628.

Carl, D., Gupta, V. and Javidan, M. (2004). Power distance. in R.J. House, P.J. Hanges, M. Javidan, P.W. Dorfman and V. Gupta (Eds.), Culture, Leadership, and Organizations, Thousand Oaks, CA: Sage, pp. 513-563.

Chang, S., Gong, Y., Way, S.A. and Jia, L. (2013). Flexibility-oriented HRM systems, absorptive capacity, and market responsiveness and firm innovativeness, Journal of Management, 39, 1924-1951.

Chen, C.-J. and Huang, J.-W. (2009). Strategic human resource practices and innovation performance - The mediating role of knowledge management capacity, Journal of Business Research, 62, 104-114.

Chen, H., Chiang, R.H. and Storey, V.C. (2012). Business intelligence and analytics: from big data to big impact, MIS quarterly, 36, 1165-1188.

Chesbrough, H. (2003). Open Innovation: The New Imperative for Creating and Profiting from Technology, Boston, MA: Harvard Business School Press.

Cheung, G.W. and Lau, R.S. (2011). A direct comparison approach for testing measurement invariance, Organizational Research Methods, 15, 167-198. 
Cheung, G.W. and Rensvold, R.B. (2002). Evaluating goodness-of-fit indexes for testing measurement invariance, Structural Equation Modelling, 9, 233-255.

Collins, C.J. and Smith, K.G. (2006). Knowledge exchange and combination: The role of human resource practices in the performance of high-technology firms, Academy of Management Journal, 49, 544-560.

Conduit, J. and Mavondo, F.T. (2001). How critical is internal customer orientation to market orientation?, Journal of Business Research, 51, 11-24.

Cooke, F.L. and Saini, D.S. (2010). (How) does the HR strategy support an innovation oriented business strategy? An investigation of institutional context and organizational practices in Indian firms, Human Resource Management, 49, 377-400.

Daft, R.L. (1978). A dual-core model of organizational innovation, Academy of Management Journal, 21, 193-210.

Damanpour, F. and Aravind, D. (2006). Product and process innovations: A review of organizational and environmental determinants. in J. Hage and M. Meeus (Eds.), Innovation, Science, and Institutional Change, Oxford: Oxford University Press, pp. 38-66.

Daniels, M.A. and Greguras, G.J. (2014). Exploring the nature of power distance implications for micro-and macro-level theories, processes, and outcomes, Journal of Management, 40, 1202-1229.

Day, G.S. (1994a). The capabilities of market-driven organizations, Journal of Marketing, 58, 37-52.

Day, G.S. (1994b). Continuous learning about markets, California Management Review, 36, 9-31.

Erez, M. and Nouri, R. (2010). Creativity: The influence of cultural, social, and work contexts, Management and Organization Review, 6, 351-370.

Fang, S.-R., Chang, E., Ou, C.-C. and Chou, C.-H. (2014). Internal market orientation, market capabilities and learning orientation, European Journal of Marketing, 48, 170-192.

Forsyth, J. and Boucher, L. (2015). Why big data is not enough, Research World, 2015, 2627.

Foss, N.J., Laursen, K. and Pedersen, T. (2011). Linking customer interaction and innovation: The mediating role of new organizational practices, Organization Science, 22, 980-999.

Fu, N., Flood, P.C., Bosak, J., Morris, T. and O'Regan, P. (2015). How do high performance work systems influence organizational innovation in professional service firms?, Employee Relations, 37, 209-231.

Gelfand, M.J., Nishii, L.H. and Raver, J.L. (2006). On the nature and importance of cultural tightness-looseness, Journal of Applied Psychology, 91, 1225.

Greenley, G.E. and Foxall, G.R. (1997). Multiple stakeholder orientation in UK companies and the implications for company performance, Journal of Management Studies, 34, 259-284. 
Greenley, G.E. and Foxall, G.R. (1998). External moderation of associations among stakeholder orientations and company performance, International Journal of Research in Marketing, 15, 51-69.

Greenley, G.E., Hooley, G.J. and Rudd, J.M. (2005). Market orientation in a multiple stakeholder orientation context: implications for marketing capabilities and assets, Journal of Business Research, 58, 1483-1494.

Guzzo, R.A. and Noonan, K.A. (1994). Human resource practices as communications and the psychological contract, Human Resource Management, 33, 447-462.

Han, J.K., Kim, N. and Srivastava, R.K. (1998). Market orientation and organizational performance: Is innovation a missing link?, Journal of Marketing, 62, 30-45.

Heugens, P.P. and Lander, M.W. (2009). Structure! Agency!(and other quarrels): A metaanalysis of institutional theories of organization, Academy of Management Journal, 52, 6185.

Heusinkveld, S., Benders, J. and van den Berg, R.-J. (2009). From market sensing to new concept development in consultancies: The role of information processing and organizational capabilities, Technovation, 29, 509-516.

Hofstede, G. (1980). Culture's Consequences: International Differences in Work-Related Values, Beverly Hills, CA: Sage.

Hooley, G., Broderick, A. and Möller, K. (1998). Competitive positioning and the resourcebased view of the firm, Journal of Strategic Marketing, 6, 97-116.

Hu, L.T. and Bentler, P.M. (1999). Cutoff criteria for fit indexes in covariance structure analysis: Conventional criteria versus new alternatives, Structural Equation Modeling: A Multidisciplinary Journal, 6, 1-55.

Huber, G.P. (1991). Organizational learning: The contributing processes and the literatures, Organization Science, 2, 88-115.

Jiang, J., Wang, S. and Zhao, S. (2012). Does HRM facilitate employee creativity and organizational innovation? A study of Chinese firms, The International Journal of Human Resource Management, 23, 4025-4047.

Johne, A. (1999). Using market vision to steer innovation, Technovation, 19, 203-207.

Jones, G.K. and Davis, H.J. (2000). National Culture and Innovation: Implications for Locating Global R\& D Operations, MIR: Management International Review, 40, 11-39.

Kale, P. and Singh, H. (2007). Building firm capabilities through learning: the role of the alliance learning process in alliance capability and firm-level alliance success, Strategic Management Journal, 28, 981-1000.

Kirca, A.H., Jayachandran, S. and Bearden, W.O. (2005). Market orientation: A metaanalytic review and assessment of its antecedents and impact on performance, Journal of Marketing, 69, 24-41. 
Koc, E. (2013). Power distance and its implications for upward communication and empowerment: Crisis management and recovery in hospitality services, The International Journal of Human Resource Management, 24, 3681-3696.

Lau, C.M. and Ngo, H.Y. (2004). The HR system, organizational culture, and product innovation, International Business Review, 13, 685-703.

Laursen, K. and Salter, A. (2006). Open for innovation: The role of openness in explaining innovation performance among UK manufacturing firms, Strategic Management Journal, 27 , 131-150.

Lepak, D.P. and Snell, S.A. (2002). Examining the human resource architecture: The relationships among human capital, employment, and human resource configurations, Journal of Management, 28, 517-543.

Lepak, D.P., Takeuchi, R., Erhardt, N.L. and Colakoglu, S. (2006). Emerging perspectives on the relationship between HRM and performance. in R.J. Burke and C.L. Cooper (Eds.), The Human Resources Revolution: Why Putting People First Matters, Amsterdam: Elsevier, pp. $31-54$.

Lin, C.-H. and Sanders, K. (2017). HRM and innovation: A multi-level organisation learning perspective, Human Resource Management Journal, 27, 300-317.

Lindell, M.K. and Whitney, D.J. (2001). Accounting for common method variance in crosssectional research designs, Journal of Applied Psychology, 86, 114-121.

Liu, D., Gong, Y., Zhou, J. and Huang, J.-C. (2016). Human resource systems, employee creativity, and firm innovation: The moderating role of firm ownership, Academy of Management Journal, Advance Online Publication.

Lopez-Cabrales, A., Perez-Luño, A. and Cabrera, R.V. (2009). Knowledge as a mediator between HRM practices and innovative activity, Human Resource Management, 48, 485-503.

Luk, C.-L., Yau, O.H.M., Sin, L.Y.M., Tse, A.C.B., Chow, R.P.M. and Lee, J.S.Y. (2008). The effects of social capital and organizational innovativeness in different institutional contexts, Journal of International Business Studies, 39, 589-612.

Maseland, R. and Hoorn, A.v. (2009). Explaining the negative correlation between values and practices: A note on the Hofstede - GLOBE debate, Journal of International Business Studies, 40, 527-532.

Morgan, N.A., Slotegraaf, R.J. and Vorhies, D.W. (2009). Linking marketing capabilities with profit growth, International Journal of Research in Marketing, 26, 284-293.

Morrison, E.W. and Milliken, F.J. (2000). Organizational silence: A barrier to change and development in a pluralistic world, Academy of Management Review, 25, 706-725.

Narver, J.C. and Slater, S.F. (1990). The effect of a market orientation on business profitability, Journal of Marketing, 54, 20-35. 
Neves, P. and Eisenberger, R. (2012). Management communication and employee performance: The contribution of perceived organizational support, Human Performance, 25, 452-464.

Newman, K.L. and Nollen, S.D. (1996). Culture and congruence: The fit between management practices and national culture, Journal of International Business Studies, 27, 753-779.

Nishii, L.H., Lepak, D.P. and Schneider, B. (2008). Employee attributions of the "why" of HR practices: Their effects on employee attitudes and behaviors, and customer satisfaction, Personnel psychology, 61, 503-545.

Nishii, L.H. and Wright, P.M. (2008). Variability within organizations: Implications for strategic human resources management in D.B. Smith (Ed.), The people make the place: Dynamic linkages between individuals and organizations Mahwah, NJ: Erlbaum, pp. 225248.

Nonaka, I. and Takeuchi, H. (1995). The Knowledge-Creating Company: How Japanese Companies Create the Dynamics of Innovation, New York: Oxford University Press.

Nonaka, I., Toyama, R. and Nagata, A. (2000). A firm as a knowledge-creating entity: a new perspective on the theory of the firm, Industrial and Corporate Change, 9, 1-20.

Olavarrieta, S. and Friedmann, R. (2008). Market orientation, knowledge-related resources and firm performance, Journal of Business Research, 61, 623-630.

Pass, M.W., Evans, K.R. and Schlacter, J.L. (2004). Sales force involvement in CRM information systems: Participation, support, and focus, Journal of Personal Selling \& Sales Management, 24, 229-234.

Peccei, R. and Rosenthal, P. (2001). Delivering customer-oriented behaviour through empowerment: An empirical test of HRM assumptions, Journal of Management Studies, 38, 831-857.

Perdomo-Ortiz, J., Gonzalez-Benito, J. and Galende, J. (2009). An analysis of the relationship between total quality management-based human resource management practices and innovation, The International Journal of Human Resource Management, 20, 1191-1218.

Plakoyiannaki, E., Tzokas, N., Dimitratos, P. and Saren, M. (2008). How critical is employee orientation for customer relationship management? Insights from a case study, Journal of Management Studies, 45, 268-293.

Podsakoff, P.M., MacKenzie, S.B. and Podsakoff, N.P. (2012). Sources of method bias in social science research and recommendations on how to control it, Annual Review of Psychology, 63, 539-569.

Preacher, K.J. and Hayes, A.F. (2004). SPSS and SAS procedures for estimating indirect effects in simple mediation models, Behavior research methods, instruments, \& computers, $36,717-731$. 
Priem, R.L., Li, S. and Carr, J.C. (2012). Insights and new directions from demand-side approaches to technology innovation, entrepreneurship, and strategic management research, Journal of Management, 38, 346-374.

Rabl, T., Jayasinghe, M., Gerhart, B. and Kühlmann, T.M. (2014). A meta-analysis of country differences in the high-performance work system-business performance relationship: The roles of national culture and managerial discretion, Journal of Applied Psychology, 99, 1011-1041.

Radnor, Z. and Robinson, J. (2000). Benchmarking innovation: A short report, Creativity and Innovation Management, 9, 3-13.

Rinne, T., Steel, G.D. and Fairweather, J. (2012). Hofstede and Shane revisited: The role of power distance and individualism in national-level innovation success, Cross-Cultural Research, 46, 91-108.

Robert, C., Probst, T.M., Martocchio, J.J., Drasgow, F. and Lawler, J.J. (2000). Empowerment and continuous improvement in the United States, Mexico, Poland, and India: predicting fit on the basis of the dimensions of power distance and individualism, Journal of Applied Psychology, 85, 643-658.

Rowley, J., Baregheh, A. and Sambrook, S. (2011). Towards an innovation-type mapping tool, Management Decision, 49, 73-86.

Schneider, B. and Bowen, D.E. (1985). Employee and customer perceptions of service in banks: Replication and extension, Journal of Applied Psychology, 70, 423-433.

Seeck, H. and Diehl, M.-R. (2016). A literature review on HRM and innovation-taking stock and future directions, The International Journal of Human Resource Management, 1-32.

Shane, S., Venkataraman, S. and MacMillan, I. (1995). Cultural differences in innovation championing strategies, Journal of Management, 21, 931-952.

Shipton, H., Fay, D., West, M., Patterson, M. and Birdi, K. (2005). Managing people to promote innovation, Creativity and Innovation Management, 14, 118-128.

Shipton, H., West, M.A., Dawson, J., Birdi, K. and Patterson, M. (2006). HRM as a predictor of innovation, Human Resource Management Journal, 16, 3-27.

Stata, R. (1989). Organizational learning: The key to management innovation, Sloan Management Review, 30, 63-74.

Sturman, M.C., Shao, L. and Katz, J.H. (2012). The effect of culture on the curvilinear relationship between performance and turnover, Journal of Applied Psychology, 97, 46-62.

Takeuchi, R., Chen, G. and Lepak, D.P. (2009). Through the looking glass of a social system: Cross-level effects of high-performance work systems on employees' attitudes, Personnel Psychology, 62, 1-29.

Tourish, D. (2005). Critical upward communication: Ten commandments for improving strategy and decision making, Long Range Planning, 38, 485-503. 
Ulrich, D. and Brockbank, W. (2005). The HR Value Proposition, Boston, MA: Harvard Business School Press.

Vandenberghe, C., Bentein, K., Michon, R., Chebat, J.-C., Tremblay, M. and Fils, J.-F. (2007). An examination of the role of perceived support and employee commitment in employee-customer encounters, Journal of Applied Psychology, 92, 1177-1187.

von Hippel, E. (1998). Economics of product development by users: The impact of "sticky" local information, Management Science, 44, 629-644.

Vuori, T.O. and Huy, Q.N. (2016). Distributed attention and shared emotions in the innovation process: How Nokia lost the Smartphone battle, Administrative Science Quarterly, $61,9-51$.

West, M.A. and Anderson, N.R. (1996). Innovation in top management teams, Journal of Applied psychology, 81, 680-693.

Whitener, E.M. (2001). Do "high commitment" human resource practices affect employee commitment? A cross-level analysis using hierarchical linear modeling, Journal of Management, 27, 515-535.

Xiao, Z. and Björkman, I. (2006). High commitment work systems in Chinese organizations: A preliminary measure, Management and Organization Review, 2, 403-422.

Zahra, S.A. and George, G. (2002). Absorptive capacity: A review, reconceptualization, and extension, Academy of Management Review, 27, 185-203.

Zhang, Y. and Begley, T.M. (2011). Power distance and its moderating impact on empowerment and team participation, The International Journal of Human Resource Management, 22, 3601-3617.

Zhou, K.Z. and Li, C.B. (2012). How knowledge affects radical innovation: Knowledge base, market knowledge acquisition, and internal knowledge sharing, Strategic Management Journal, 33, 1090-1102.

Zhou, Y., Hong, Y. and Liu, J. (2013). Internal commitment or external collaboration? The impact of human resource management systems on firm innovation and performance, Human Resource Management, 52, 263-288. 
Table 1 Descriptive statistics on samples

\begin{tabular}{llll}
\hline Countries & $\mathrm{N}$ & Language & Net response rate (\%) \\
\hline UK & 354 & English & 10 \\
Ireland & 478 & English & 47 \\
Austria & 163 & German & 16 \\
Finland & 300 & English & 24 \\
New Zealand & 368 & English & 45 \\
Australia & 207 & English & 20 \\
Hungary & 368 & Hungary & 21 \\
Slovenia & 470 & Slovene & 60 \\
Greece & 290 & Greek & 43 \\
Netherlands & 134 & Dutch & 10 \\
Germany & 205 & German & 16 \\
US & 141 & English & 11 \\
Brazil & 277 & Portuguese & 10 \\
Total & 3,755 & Mean response rate & 26 \\
\hline
\end{tabular}


Table 2 Correlation matrix and summary statistics in the pooled sample

\begin{tabular}{|c|c|c|c|c|c|c|c|c|c|c|c|c|c|c|}
\hline Variable & Mean & s.d. & 1 & 2 & 3 & 4 & 5 & 6 & 7 & 8 & 9 & 10 & 11 & 12 \\
\hline 1. $\mathrm{HR}$ & 3.74 & .81 & & & & & & & & & & & & \\
\hline 2. Market-sensing capability & 3.63 & .70 & $.21^{* *}$ & & & & & & & & & & & \\
\hline 3. Product innovation & 3.47 & .69 & $.16^{* *}$ & $.30^{* *}$ & & & & & & & & & & \\
\hline 4. Process innovation & 3.51 & .82 & $.32^{* *}$ & $.41^{* *}$ & $.47^{* *}$ & & & & & & & & & \\
\hline 5. Market competition & 3.89 & .59 & $.18^{* *}$ & $.09^{* *}$ & $.13^{* *}$ & $.17^{* *}$ & & & & & & & & \\
\hline 6. Medium size & .36 & .48 & .01 & -.03 & -.00 & -.01 & .02 & & & & & & & \\
\hline 7. Large size & .17 & .38 & $.06^{* *}$ & $-.04^{*}$ & -.03 & -.02 & .01 & $-.34^{* *}$ & & & & & & \\
\hline 8. FMCG & .14 & .34 & -.02 & -.01 & -.01 & -.01 & -.02 & .03 & $.04^{*}$ & & & & & \\
\hline 9. $\mathrm{MaC}$ & .15 & .35 & -.00 & -.01 & $-.05^{*}$ & -.00 & .02 & $.04^{* *}$ & -.03 & $-.16^{* *}$ & & & & \\
\hline 10. CIE & .12 & .32 & -.01 & -.04 & .02 & -.01 & .01 & -.01 & -.02 & $-.15^{* *}$ & $-.15^{* *}$ & & & \\
\hline 11. Business service industry & .18 & .39 & $.08^{* *}$ & $.05^{* *}$ & $.06^{*}$ & $.03^{*}$ & .01 & $-.06^{* *}$ & .01 & $-.19^{* *}$ & $-.19^{* *}$ & $-.17^{* *}$ & & \\
\hline 12. Consumer service industry & .09 & .28 & .00 & .02 & -.02 & .02 & $-.04^{*}$ & -.01 & .02 & $-.12^{* *}$ & $-.13^{* *}$ & $-.11^{* *}$ & $-.14^{* *}$ & \\
\hline 13. Other industries & .18 & .38 & -.02 & $-.04^{*}$ & -.02 & -.02 & .00 & -.00 & -.01 & $-.18^{* *}$ & $-.19^{* *}$ & $-.17^{* *}$ & $-.22^{* *}$ & $-.14^{* *}$ \\
\hline
\end{tabular}

Notes: $\mathrm{N}=3,755$

$\mathrm{FMCG}=$ fast moving consumer goods industry; $\mathrm{MaC}=$ materials and components industry; $\mathrm{CIE}=$ capital industrial equipment industry .

${ }^{*} p<.05,{ }^{* *} p<.01$, two-tailed. 
Table 3. Path coefficients in each country and in the pooled sample

\begin{tabular}{|c|c|c|c|c|c|c|c|c|c|c|c|c|c|c|}
\hline & NL & $\mathrm{AU}$ & US & NZ & FI & AT & IE & UK & $\mathrm{DE}$ & BR & SI & GR & $\mathrm{HU}$ & $\begin{array}{l}\text { Pooled } \\
\text { sample }\end{array}$ \\
\hline $\mathrm{HR} \rightarrow$ market-sensing & $.34^{*}$ & $.23^{\dagger}$ & $.43^{* *}$ & .10 & .10 & $.32^{\dagger}$ & $.28^{* *}$ & $.25^{* *}$ & $.52^{* *}$ & $.35^{* *}$ & $.27^{* *}$ & $.34^{* *}$ & $.39^{* *}$ & $.28^{* *}$ \\
\hline $\begin{array}{l}\text { market-sensing } \rightarrow \text { product } \\
\text { innovation }\end{array}$ & $.52^{* *}$ & $.51^{* *}$ & $.40^{*}$ & $.31^{* *}$ & $.53^{* *}$ & $.55^{\dagger}$ & $.41^{* *}$ & $.24^{* *}$ & $.45^{*}$ & $.61^{* *}$ & $.32^{* *}$ & $.35^{* *}$ & $.42^{* *}$ & $.43^{* *}$ \\
\hline $\begin{array}{l}\text { indirect effect HRM } \rightarrow \\
\text { product innovation }\end{array}$ & $\begin{array}{l}.16^{\dagger} \\
{[-.00, .49]}\end{array}$ & $\begin{array}{l}.12^{\dagger} \\
{[-.00, .30]}\end{array}$ & $\begin{array}{l}.17^{*} \\
{[.03, .45]} \\
\end{array}$ & $\begin{array}{l}.03 \\
{[-.02, .09]}\end{array}$ & $\begin{array}{l}.04 \\
{[-.04, .14]}\end{array}$ & $\begin{array}{l}.14 \\
{[-.07, .70]}\end{array}$ & $\begin{array}{l}.09^{* *} \\
{[.04, .16]}\end{array}$ & $\begin{array}{l}.05^{* *} \\
{[.01, .12]}\end{array}$ & $\begin{array}{l}.16^{*} \\
{[.02, .73]}\end{array}$ & $\begin{array}{l}.14^{* *} \\
{[.06, .25]}\end{array}$ & $\begin{array}{l}.08^{* *} \\
{[.03, .16]}\end{array}$ & $\begin{array}{l}.13^{* *} \\
{[.05, .24]}\end{array}$ & $\begin{array}{l}.15^{* *} \\
{[.06, .31]}\end{array}$ & $\begin{array}{l}.09^{* *} \\
{[.07, .12]}\end{array}$ \\
\hline $\begin{array}{l}\text { direct effect HRM } \rightarrow \text { product } \\
\text { innovation }\end{array}$ & $-.50^{* *}$ & .03 & -.20 & .10 & -.03 & .04 & $.13^{*}$ & .07 & -.08 & -.05 & $.14^{\dagger}$ & $.14^{\dagger}$ & .06 & $.08^{* *}$ \\
\hline $\begin{array}{l}\text { market-sensing } \rightarrow \text { process } \\
\text { innovation }\end{array}$ & $.43^{*}$ & $.51^{* *}$ & $.40^{*}$ & $.28^{* *}$ & $.72^{* *}$ & $.66^{*}$ & $.38^{* *}$ & $.58^{* *}$ & $.65^{* *}$ & $.54^{* *}$ & $.49^{* *}$ & $.39^{* *}$ & $.57^{* *}$ & $.49^{* *}$ \\
\hline $\begin{array}{l}\text { indirect effect HRM } \rightarrow \\
\text { process innovation }\end{array}$ & $\begin{array}{l}.14^{*} \\
{[.00, .45]}\end{array}$ & $\begin{array}{l}.12^{\dagger} \\
{[-.00, .30]}\end{array}$ & $\begin{array}{l}.20^{*} \\
{[.05, .49]}\end{array}$ & $\begin{array}{l}.03 \\
{[-.02, .09]}\end{array}$ & $\begin{array}{l}.06 \\
{[-.07, .20]}\end{array}$ & $\begin{array}{l}.19 \\
{[-.11,1.00]}\end{array}$ & $\begin{array}{l}.10^{* *} \\
{[.05, .17]}\end{array}$ & $\begin{array}{l}.12^{* *} \\
{[.03, .23]}\end{array}$ & $\begin{array}{l}.32^{* *} \\
{[.11,1.16]}\end{array}$ & $\begin{array}{l}.14^{* *} \\
{[.06 ., 24]}\end{array}$ & $\begin{array}{l}.14^{* *} \\
{[.06, .24]}\end{array}$ & $\begin{array}{l}.13^{* *} \\
{[.06, .25]}\end{array}$ & $\begin{array}{l}.22^{* *} \\
{[.09, .39]}\end{array}$ & $\begin{array}{l}.12^{* *} \\
{[.10, .15]}\end{array}$ \\
\hline $\begin{array}{l}\text { direct effect HRM } \rightarrow \text { process } \\
\text { innovation }\end{array}$ & -.15 & $.21^{*}$ & .23 & $.25^{* *}$ & $.18^{*}$ & .20 & $.22^{* *}$ & .12 & .04 & .13 & $.25^{* *}$ & $.38^{* *}$ & $.24^{*}$ & $.21^{* *}$ \\
\hline $\begin{array}{l}\text { product innovation } \leftrightarrow \\
\text { process innovation }\end{array}$ & $.92^{*}$ & $.49^{* *}$ & $.55^{* *}$ & $.33^{* *}$ & .11 & .29 & $.50^{* *}$ & $.51^{* *}$ & $.53^{* *}$ & $.33^{* *}$ & $.45^{* *}$ & $.38^{* *}$ & $.28^{*}$ & $.44^{* *}$ \\
\hline
\end{tabular}

Notes: Except for the indirect effects, all other path coefficients are standardized coefficients. The indirect effects are unstandardized coefficients based on bootstrapping 10,000 times.

${ }^{\dagger} \mathrm{p}<.10,{ }^{*} p<.05,{ }^{* *} p<.01$, two-tailed.

$\mathrm{NL}=$ Netherlands, $\mathrm{AU}=$ Australia, $\mathrm{US}=$ United States, NZ = New Zealand, FI = Finland; AT= Austria; IE=Ireland; UK=United Kingdom; $\mathrm{DE}=$ Germany; $\mathrm{BR}=$ Brazil; SI=Slovenia; $\mathrm{GR}=$ Greece; $\mathrm{HU}=$ Hungary 


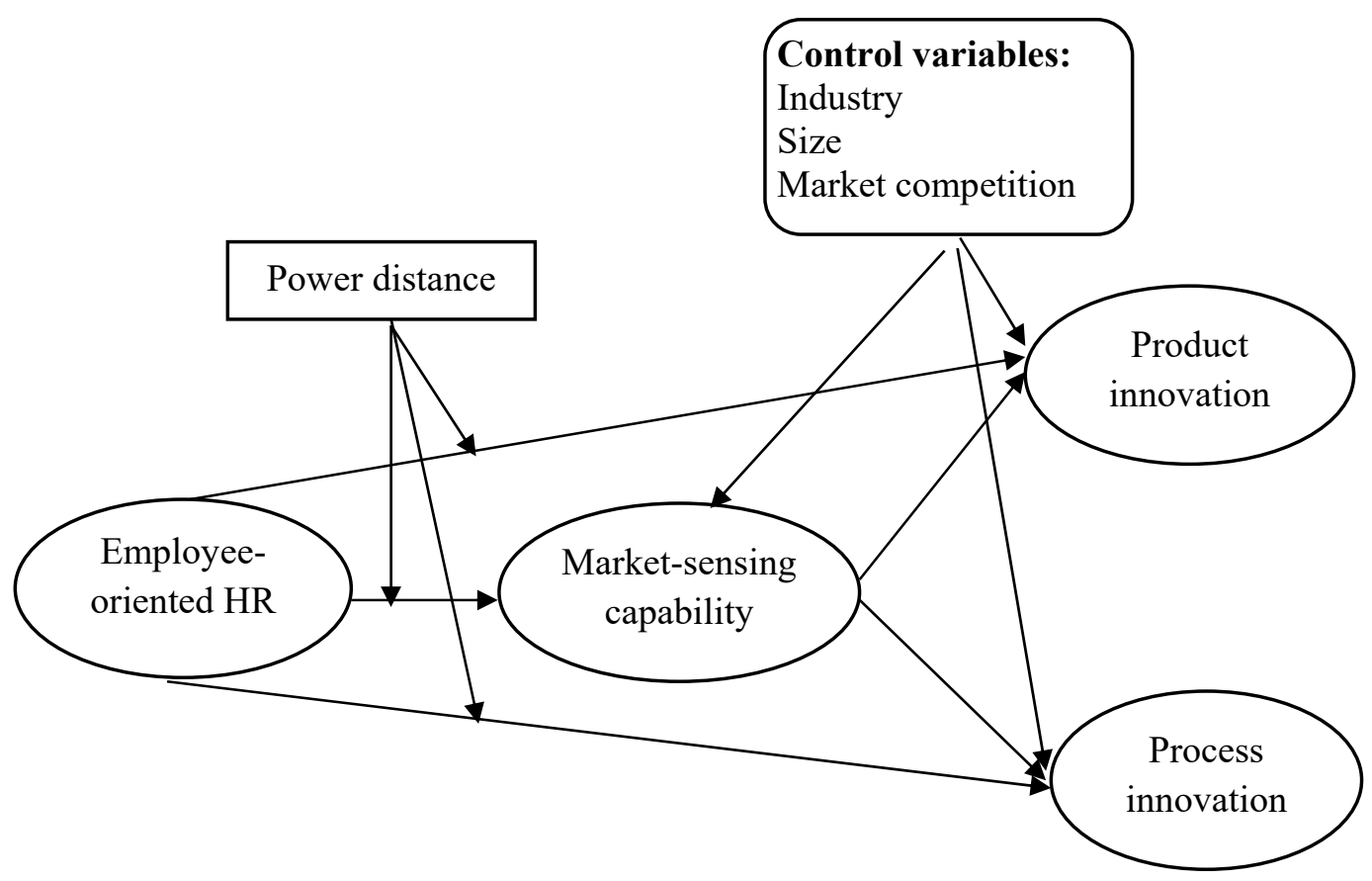

Figure 1: Conceptual research model 
Low power distance countries

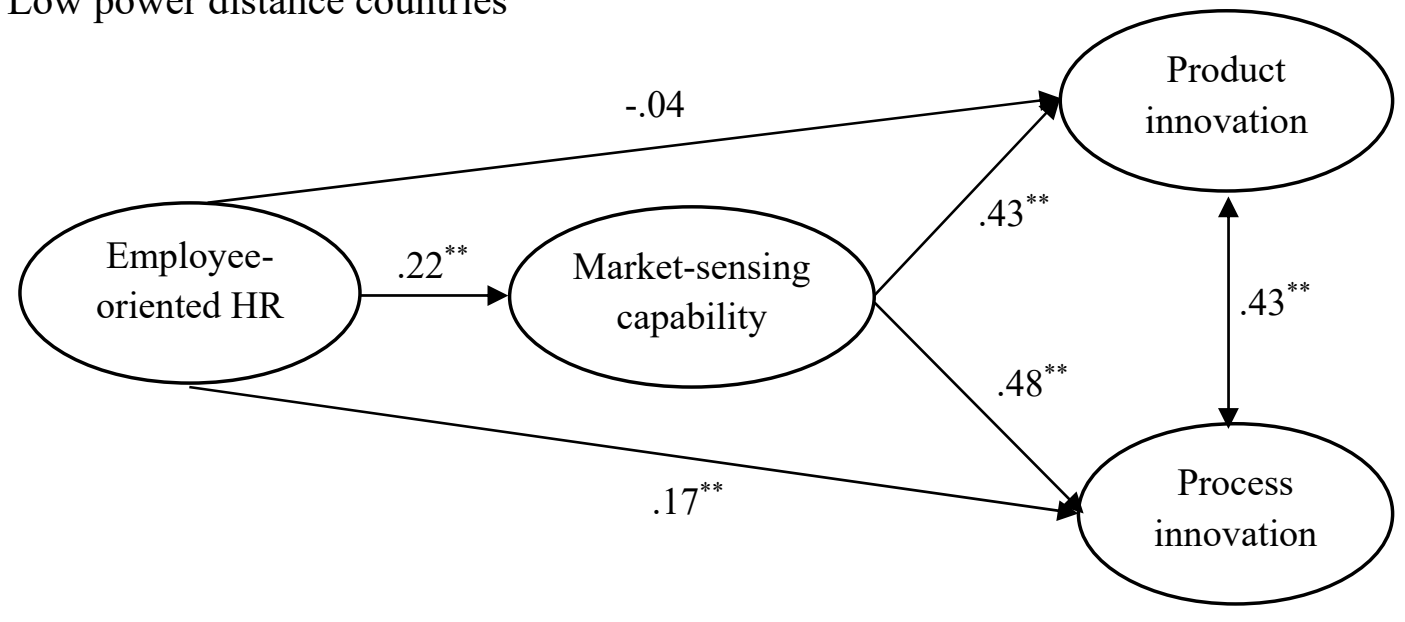

High power distance countries

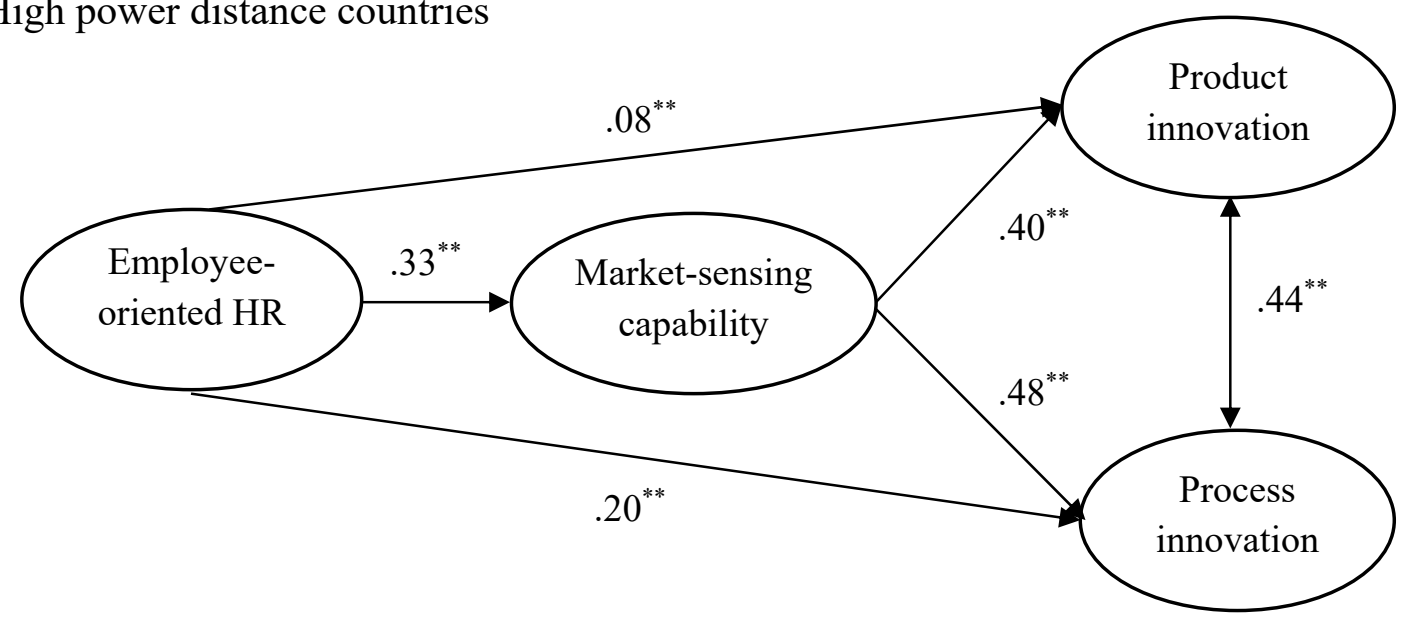

Figure 2: path coefficients in the low and high power distance countries.

Note: Standardized path coefficients are reported.

${ }^{*} p<.05,{ }^{* *} p<.01$, two-tailed. 